\title{
nature
}

\section{A squandered opportunity}

The sacking of France's science and education minister was unavoidable. His successor would do well to take on board some of Claude Allègre's goals, but also to learn from his mistakes in reforming French and European research.

A French newspaper joked this week that Claude Allègre, France's departing minister for research and education, might prefer to avoid the traditional courtyard ceremony of handing power over to his successor, in case ministry staff leaned out of their windows to applaud his departure. The jab is unkind. But it speaks volumes about Allègre's uncanny ability to make himself unpopular, a trait directly responsible for his downfall. Prime minister Lionel Jospin did not part lightly with his lifelong friend, but Allègre's arrogance and inability to consult or negotiate effectively were the anathema of the modern 'listening' government that Jospin aspires to create. In practice, by provoking defensive hostility in others, Allègre reinforced the very conservatism he rightly set out to overcome. The result has been deadlock on most important fronts. In the end, Allègre so isolated himself from the grass roots of the teaching profession that he no longer had the authority to secure change, and Jospin had no choice but to dispose of him. In the circumstances, it is a relief that the option of retaining Allègre in a narrower role as research minister was not pursued.

Entering office in 1997, Allègre recognized the problems of French research as clearly as anyone, and had some excellent goals. Last year's law on innovation, thrashed out with the then industry minister, Dominique Strauss-Kahn, represents a major step towards removing obsolete restrictions on public scientists' involvement with private companies. Also praiseworthy were Allègre's plans to shift resources towards investigator-driven research, and to encourage greater autonomy among young researchers - who, under the current feudal French laboratory system, are tied to their laboratory head's apron-strings. Funding has improved slightly, some jobs have been created, and all high schools are now connected to the Internet.

\section{Wrong reforms}

But so much more needed to be achieved, and, given the underlying support for change in the research community, the blame for failures rests largely with Allègre. Instead of the pragmatic modernization of practices, each tuned to particular situations at the grass roots, the ministry chose high-profile reforms of, for example, whole funding agencies, usually preceded by a blitzkrieg on their staff and practices - from the fat "mammoth" of the education system to the "chloroformed" trade unions. When teachers struggling with bursting classrooms called for more posts, the ministry unfairly accused the profession of excessive absenteeism. Reform, often simplistically modelled on the Anglo-Saxon system, seemed often to become an end in itself. Rhetoric replaced focused objectives and detailed means of achieving them.

The pattern became familiar: bold but poorly thought-out reforms were rolled out with fanfare, researchers took to the boulevards, the ministry backed down, and everyone agreed to unambitious plans that could have been reached easily and quickly - witness this week's reform of the Centre National de la Recherche Scientifique (see page 426). Valuable time and energy have been lost as a result of sterile confrontations between researchers and a ministry that appeared to be unable to listen. A more productive strategy would have been for the ministry and the research community to identify critical areas where tangible progress could be achieved. As a result, three years after coming to power, the government's overall achievements in research reform could be hidden under a pebble beneath the virtually unbroken palisades of France's research institutions.

\section{Power problems}

Roger-Gérard Schwartzenberg, Allègre's successor as research minister, would do well to study the causes of this failure. Apart from Allègre's own failings, his administration clung to an outmoded form of government. Ironically, Allègre, who never ceased to attack the unhealthy power exerted by French research mandarins and technocrats, was a pure product of this system. Power over a wide range of strategies and decisions was centralized at the ministry in the hands of small clans of powerful autocratic individuals and lobbies. Such overly top-down approaches to government are problematic, if not obsolete, in this fast-moving scientific era, where appropriate competences are widely distributed. Allègre adopted the role of a mainframe computer, and by undermining the autonomy of the research agencies, and by cutting himself off from them, he denied himself the power and speed of a network.

All the more frustrating, therefore, that the problems acknowledged as priorities by researchers are virtually identical to those that most troubled Allègre: the lack of independence of young scientists is one, the bloated system of evaluation another. And then there is the long-recognized rigidity of a system where some scientists enjoy full-time posts in the research agencies while their colleagues in the universities - often young scientists in their prime - struggle to find time for research alongside excessive teaching loads. But research agencies are reforming themselves, and while tough decisions will always be needed in some situations, an astute minister would realize that, in many areas, the agencies and the research community are badly needed allies. Schwartzenberg will need to move swiftly to rebuild confidence in the research community, and seek to bring about negotiated change.

But he should also do a better job than his predecessor, and ministers in other countries for that matter, at the international level, where there are glaring opportunities in coordinating and planning sustained and cost-effective support for the second-generation Internet, international bioinformatics facilities, and other costly research facilities that serve large and diverse communities. As the recent funding fiasco at the European Bioinformatics Institute shows, insufficient national government attention has been paid to the crucial issue of European infrastructure. And whatever the merits of the recent French decision to contribute to building a new synchrotron in Britain, it was not the coherent pro-European exercise it was billed to be, but a hastily arranged cost-saving exercise.

France takes over the rolling presidency of the European Union in July. The biggest single opportunity facing Schwartzenberg - and his counterparts in other European countries - is to make progress in the long-neglected challenge of building a scientifically coherent Europe in earnest. 